\title{
Labour Employment and Income Generation from Agro- forestry System in U.S. Nagar District of Uttarakhand, India
}

\author{
Anuj Kumar* and S.K. Srivastava \\ Department of Agricultural Economics, College of Agriculture, G.B. Pant University of Agriculture and Technology, Pantnagar \\ - 263 145, Uttarakhand, India \\ "Corresponding author: anuj35955@gmail.com
}

\begin{abstract}
The paper has examined the labour employment generation of the prevailing agro-forestry system. Two block of Udham Singh Nagar was selected for study purpose in which two spacing was followed by sample farmers i.e. $7 \mathrm{~m} \times 3 \mathrm{~m}$ and $5 \mathrm{~m} \times 4 \mathrm{~m}$. Study was conducted by taking in to labour engaged in the Agro forestry System. Aggregate measures were used to determine the labour employed in agro-forestry system in different years of plantation. The result indicated that Agro-forestry with spacing $7 \mathrm{~m} \times 3 \mathrm{~m}$ require less labour to be employed in comparison to spacing $5 \mathrm{~m} \times 4 \mathrm{~m}$. The result of study has suggested that policy support in terms promotion is to provide some incentive to agro-forestry farmers.
\end{abstract}

Keywords: Agro-forestry, Employment, Spacing, Income, Labour

Agro-forestry is a land use system which integrates trees and shrubs on farm lands and rural landscapes to enhance productivity, profitability, diversity and ecosystem sustainability. Agro-forestry systems include both traditional and modern land-use systems, where trees are managed together with crops and animal production systems in agricultural settings. It is practiced in both irrigated and rain fed conditions, where it produces food, fuel, fodder, timber, and fibre contributes to food, nutritional and ecological security, sustains livelihoods, alleviates poverty and promotes productive and resilient cropping and farming environments (Saxena, 2000). It also has the potential to enhance ecosystem services through carbon storage, prevention of deforestation, biodiversity conservation, and soil and water conservation. In addition, when strategically applied on a large scale, with appropriate mix of species, agro-forestry enables agricultural land to withstand extreme weather events, such as floods and droughts, and climate change effects. It has significant potential to provide employment to rural and urban population through production, industrial application and value addition ventures.
Poplar is among the world's fast growing industrial softwood species. Their deciduous nature and slender crown permits the intercultivation of a variety of seasonal and annual crops. However, poplar being sensitive to water logging, can check the traditional vicious cycle of rice-wheat systems in the region.

\section{Demography of Study area}

Broadly the plains and hills present different scenarios for agriculture in Uttarakhand. But in hills agro-forestry is not practiced on commercial basis as in the plains. In view of shrinkage of agricultural land and operational holdings due to expansion of urbanization, change in food habit of people, increasing population, farmers including trees in the cropping system (PHD chamber Uttarakhand, 2016). In the socio-economic structure it is shown that total area and average land holding of the marginal, small, medium and large farmers in which large farmers had more average land holding It has been observed that large farmers are allocating more land under agro-forestry due to sufficient land under acreage but small farmers hesitate to allocate 
Table 1: Land holding pattern in Uttarakhand

\begin{tabular}{|c|c|c|c|c|c|c|c|c|c|}
\hline \multirow[t]{2}{*}{$\begin{array}{l}\text { Sl. } \\
\text { No. }\end{array}$} & \multirow[t]{2}{*}{ Farm size class } & \multicolumn{2}{|c|}{ Number ('000) } & \multirow[t]{2}{*}{$\begin{array}{l}\text { Per cent } \\
\text { change }\end{array}$} & \multicolumn{2}{|c|}{$\begin{array}{c}\text { Area } \\
\text { ('000 ha) }\end{array}$} & \multirow[t]{2}{*}{$\begin{array}{l}\text { Per cent } \\
\text { change }\end{array}$} & \multicolumn{2}{|c|}{$\begin{array}{l}\text { Average Holding Size } \\
\text { (ha) }\end{array}$} \\
\hline & & 2001 & 2014 & & 2001 & 2014 & & 2001 & 2014 \\
\hline 1 & Marginal & $628(71)$ & $672(74)$ & 7.01 & $243(29)$ & $296(36)$ & 21.8 & 0.39 & 0.44 \\
\hline 2 & Small & $158(18)$ & 157 (17) & -0.63 & $221(26)$ & $225(28)$ & 1.8 & 1.40 & 1.43 \\
\hline 3 & Semi Medium and Medium & $102(11)$ & $82(8.9)$ & -19.60 & $344(41)$ & $270(33)$ & -21.51 & 4.11 & 2.64 \\
\hline 4 & Large & $1(0.1)$ & $1(0.1)$ & 0.00 & $36(4)$ & $25(3)$ & -30.56 & 36.00 & 25 \\
\hline & Total & 889 & 912 & 2.59 & 844 & 816 & -3.32 & 0.95 & 0.89 \\
\hline
\end{tabular}

Note: Marginal=below 1 ha; Small=1 to less than 2 ha; Semi-medium and Medium = 2 to less than 10 ha; Large =10 ha and above.

Note: Figures in parentheses indicate percentage to total farmers.

Source: Uttarakhand at a glance (2015), Directorate of Economics and Statistics, Dehra.

land under agro-forestry because this takes longer period to generate income and they are doing subsistence agriculture and government didn't provide any support as providing carbon credit.

\section{Map of study area}

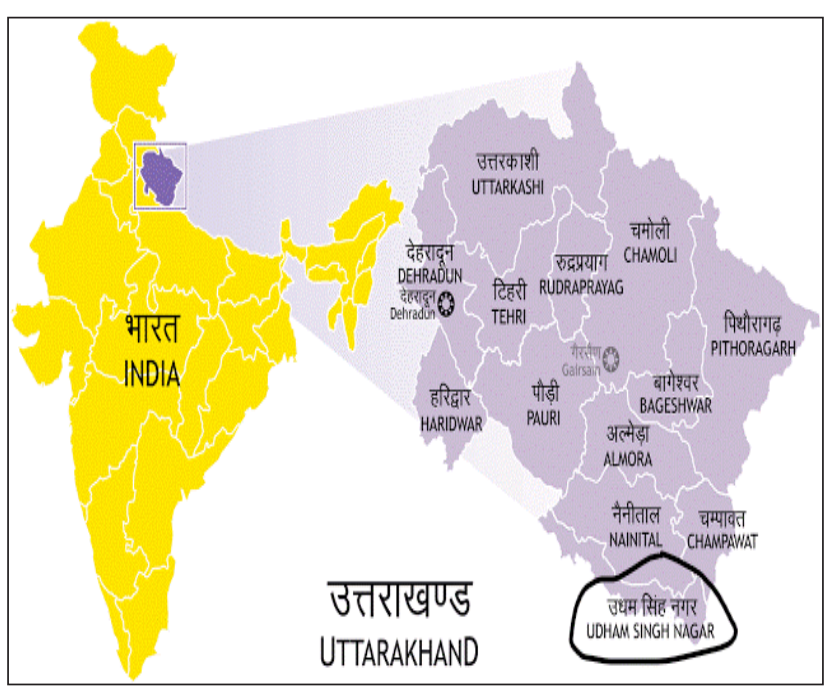

\section{MATERIALS AND METHODS}

In Uttarakhand, U.S. Nagar district is chosen purposively. Out of total 7 blocks in the U.S. Nagar district, Rudrapur and Gadarpur blocks were selected randomly to represent the district. From the list of the villages in the selected blocks, one village was selected randomly and then three adjoined villages were selected to form a cluster of four villages from each block. Secondly a list of all the farmers practicing agro-forestry was prepared. Among block and boundary plantations with poplar it was observed that majority of farmers (52.53 per cent) were practicing block plantation. Therefore, only block plantation of poplar based agro-forestry had been considered for this study. In poplar block plantation it was found that two types of spacing viz., $7 \mathrm{~m} \times 3 \mathrm{~m}$ and $5 \mathrm{~m} \times 4 \mathrm{~m}$ were followed in the selected villages. The farmers growing poplar trees of different year ranging from one to seven years were selected in both the blocks. Three farmers were selected from each of plantation year of agro-forestry for complete rotation of each of the spacings. Hence, 21 farmers following spacing $7 \mathrm{~m} \times 3 \mathrm{~m}$ and 21 farmers for spacing $5 \mathrm{~m} \times 4 \mathrm{~m}$ were selected randomly from Rudrapur as well as from Gadarpur blocks making sample size from each block of 42 farmers. Therefore, total 84 farmers were selected for completion of study.

\section{RESULTS}

From the data shown below it is clear that in spacing $7 \mathrm{~m} \times 3 \mathrm{~m}$ digging of pits required 16 labour and 4 labours in first year and second year respectively. In the last year for cutting of poplar trees labour requirement is highest i.e., 55 and total labour employed in the entire period is 248 and for per year labour required is 33.85 and in the spacing $5 \mathrm{~m} \times 4 \mathrm{~m}$ digging of pits required 18 labour and 5 labour in first year and second year respectively. In the last year for cutting of poplar trees labour requirement is highest i.e., 60 labour and total labour employed in the entire period is 294 labour required and for per year labour required is 40.13 labour. 
Table 2: Human labour employment to execute different cultivation/cultural practices followed with poplar tree in the Agro-forestry system (Man days/ha)

\begin{tabular}{|c|c|c|c|c|c|c|c|c|c|c|c|c|c|c|c|}
\hline \multirow{3}{*}{ Sl. No. } & \multirow{3}{*}{ Particulars } & \multicolumn{7}{|c|}{ Spacing $7 \mathrm{~m} \times 3 \mathrm{~m}$} & \multicolumn{7}{|c|}{ Spacing $5 \mathrm{~m} \times 4 \mathrm{~m}$} \\
\hline & & $\begin{array}{c}\text { I } \\
\text { year }\end{array}$ & $\begin{array}{c}\text { II } \\
\text { year }\end{array}$ & $\begin{array}{c}\text { III } \\
\text { year }\end{array}$ & $\begin{array}{c}\text { IV } \\
\text { year }\end{array}$ & $\begin{array}{c}\mathrm{V} \\
\text { year }\end{array}$ & $\begin{array}{c}\mathrm{VI} \\
\text { year }\end{array}$ & $\begin{array}{l}\text { VII }^{*} \\
\text { year }\end{array}$ & $\begin{array}{c}\text { I } \\
\text { year }\end{array}$ & $\begin{array}{c}\text { II } \\
\text { year }\end{array}$ & $\begin{array}{c}\text { III } \\
\text { year }\end{array}$ & $\begin{array}{c}\text { IV } \\
\text { year }\end{array}$ & $\begin{array}{c}\mathrm{V} \\
\text { year }\end{array}$ & $\begin{array}{c}\text { VI } \\
\text { year }\end{array}$ & $\begin{array}{l}\text { VII }^{*} \\
\text { year }\end{array}$ \\
\hline & & \multicolumn{7}{|c|}{ No. of Labour } & \multicolumn{7}{|c|}{ No. of Labour } \\
\hline 1 & Digging of pit & 16 & 04 & - & - & - & - & - & 18 & 05 & - & - & - & - & - \\
\hline 2 & $\begin{array}{c}\text { FYM } \\
\text { application }\end{array}$ & 06 & 02 & - & - & - & - & - & 07 & 04 & - & - & - & - & - \\
\hline 3 & Planting & 08 & 03 & - & - & - & - & - & 10 & 04 & - & - & - & - & - \\
\hline 4 & PPC & 05 & 02 & - & - & - & - & - & 06 & 03 & - & - & - & - & - \\
\hline 5 & Training & - & - & 15 & 20 & - & - & - & - & - & 21 & 26 & - & - & - \\
\hline 6 & Pruning & - & - & - & - & 27 & 35 & 13 & - & - & - & - & 32 & 42 & 14 \\
\hline 7 & Cutting & - & - & - & - & - & - & 55 & - & - & - & - & - & - & 60 \\
\hline 8 & Uprooting & - & - & - & - & - & - & 20 & - & - & - & - & - & & 22 \\
\hline 9 & Loading & - & - & - & - & - & - & 08 & - & - & - & - & - & - & 11 \\
\hline 10 & Unloading & - & - & - & - & - & - & 08 & - & - & - & - & - & - & 11 \\
\hline \multicolumn{2}{|c|}{ Total labour employed } & 35 & 11 & 15 & 20 & 27 & 36 & 104 & 41 & 16 & 19 & 26 & 32 & 42 & 118 \\
\hline \multicolumn{2}{|c|}{ Overall (entire period) } & \multicolumn{7}{|c|}{248} & \multicolumn{7}{|c|}{294} \\
\hline \multicolumn{2}{|c|}{ Per year } & \multicolumn{7}{|c|}{33.85} & \multicolumn{7}{|c|}{40.13} \\
\hline
\end{tabular}

*VII year plus includes 3 month and 15 days of VIII year also till date of harvest of poplar tree.

\section{CONCLUSION}

The labour employment in agro-forestry system was found to be more in spacing $5 \mathrm{~m} \times 4 \mathrm{~m}$ as compared to $7 \mathrm{~m} \times 3 \mathrm{~m}$. Hence, in practicing Agro-forestry farmers generate employment opportunities for rural people. As from sowing to harvesting poplar tree require more labour to grow poplar plants in their field.

\section{REFERENCES}

Ajit, et al. 2013. Modeling analysis of potential carbon sequestration under existing agro-forestry systems in three districts of Indo Gangetic plains in India. Agrofor. Syst., 87: 1129-1146.

Anjulo, A. 2009. Component interactions and their influence on the production of apple based agro-forestry system in wet temperate zone of Himachal Pradesh. Ph.D. Thesis, Nauni, Solan (H.P.) India.

Berzer, J.E., Bouvarel, L. and Auclair, D. 1991. Short rotation forestry. An agricultural case study of economic feasibility. Biresource Technology, 35(1): 41-47.

Birhani, V.K. 1993. Economics of agro-forestry on degraded land: A case study of Salla Rantella village, Hawalbagh block Distt. Almora U.P. M.Sc. Thesis, G.B.P.U. A\&T, Pantnagar.

Chabra, A. and Dhadwal, V.K. 2000. Assessment of major pools and fluxes of carbon in Indian forests. Climate Change, 64: 341-360.

Chaturvedi, A.N. 1992. Optimum rotation of harvest for poplar in farmland under agro-forestry. Indian Forester, 118(2): 81-88.
Chauhan, S.K., Sharma, S.K., Beri, V., Ritu, Yadav, S. and Gupta, N. 2010. Yield and carbon sequestration potential of wheat (Triticum aestivum)-poplar (Populus deltoides) based agri-silvicultural system. Ind. J. Agric. Sci., 80(2): 129-135.

Chauhan, S.K. and Mangat, P.S. 2006. Poplar-based agroforestry is ideal for Punjab. APA News Asia-Pacific Agroforestry, Newsletter, 28: 7-8.

Chavan, S. et al. 2014. Agro-forestry for adaptation and mitigation of climate change. Popular Kheti, 2(3): 214-220.

Dhanda, R.S. and Verma, R.K. 2001. Timber volume and weight tables of farm grown poplar (Populus deltoids Bartr. Ex Marsh.) in Punjab. Ind. Forestry, 127(1): 115-130.

Dhillon, G.S., Grewal, S.S. and Atwal, A.S. 1979. Developing agri-silvicultural practices- effect of farm trees (eucalyptus) on the adjoining crops. Indian Journal of Ecology, 6(2): 88-97.

Dhillon, M.S., Vinod, A.S. and Malik, D.P. 2001. An economic analysis of poplar cultivation. Indian Forester, 127(1): 86-90.

Dhiman, R.C. 2013. Status and impact of commercial agroforestry in India. Ind. J. Agrofor., 15: 55-67.

Dhukia, R.S., Ram, S. and Bamgarwa, K.S. 1989. Forage productivity of bean under various spacing of poplar (P. deltoids) tree in an agro-forestry system. FEBIS News Letter, 25: 31-32.

Dhyani, S.K. 2014. National Agroforestry Policy and the need for area estimation under agroforestry. Curr. Sci., 107: 9-10.

Dhyani, S.K., Handa, A.K. and Uma 2013. Area under agroforestry in India: an assessment for present status and future perspective. Ind. J. Agrofor., 15: 1-10. 
Dwivedi, R.P., Kareemulla, K., Singh, R., Rizvi, R.H. and Chauhan, J. 2007. Socio-economic analysis of agroforestry system in western Uttar Pradesh. Ind. Res. J. Ext. Edu., 7(2\&3): 18-22.

FAO, Advancing Agroforestry on the Policy Agenda 2013. A Guide for Decision-Makers (eds Buttoud, G. et al.), Agroforestry Working Paper No. 1. Food and Agriculture Organization of the United Nations, Rome, pp. 37.
FSI, India State of Forest Report 2013. Forest Survey of India, (Ministry of Environment \& Forests), Dehradun, India,

Gittinger, J.P. 1982. Economic analysis of agricultural products. John Hpkins Univ. Press, Baltimore, USA. 